\title{
THE EPOCH OF THE ENLIGHTENMENT: FROM THE VOYAGES OF PETER I TO THE IDEAS OF THE CATHERINIAN PERIOD
}

Three hundred years ago, Tsar Peter I completed one and a half years (1716-1717) of travelling in Eastern, Central, and Western Europe. The visit of the Russian monarch culminated with a visit to Paris and the establishment of regular diplomatic relations between Russia and France. This ultimately laid the groundwork for a recent series of scientific and cultural events in Russia and France, one of the most significant of which was the international conference Le deuxième grand voyage de Pierre le Grand en Europe (1716-1717), held in Paris in June 2017. Articles written on the basis of presentations at that conference comprise the thematic core of this issue of $Q R$.

The anniversary of Peter the Great's travels was mentioned during President V. V. Putin's recent visit to France and his meeting with E. Macron, the newly elected President of the Fifth Republic. The two leaders referred to the 300-year-old event during their joint press conference and while visiting the exhibition 'Tsar Peter in France, 1717' in Versailles.

The second European tour of Peter I deserves close attention and is by all means worthy of much more intensive research than has thus far been conducted. The main problem in the study of this voyage is that, unlike the first trip undertaken by the young tsar as part of the Grand Embassy in 1697-1698, modern scholarship has not yet taken a holistic approach to Peter's journey in 1716-1717. Important issues like chronology, periodisation, and Peter the Great's motives remain largely unexplored. Unlike the Grand Embassy, which had a certain objective that dictated its route, the second journey was not originally intended to be so long and extensive: the Russian monarch changed his schedule in accordance with developing circumstances, particularly those relating to diplomacy and the Great Northern War. This was also true of the visit to Paris, 'a logical serendipity'.

The results of this journey suggest that it was not merely an event in Russian history, but also had a great effect on the Pan-European context. During the tsar's second journey, Russia, for the first time in modern history, showed itself to be one of the key players in the coming partition of Europe (and indeed of the Eurocentric world). Europe had changed greatly after the War of the Spanish Succession, and was undergoing still further changes in terms of the diminishing power of Sweden, a former hegemon of the north. Europe was formulating a balance of power among the great countries, among which Russia had taken a prominent place even in the 
eyes of the most ardent skeptics. During the 1716-1717 journey, Russian diplomats improved their skills and gained clout. Meanwhile, the Russian army and fleet were becoming a familiar, albeit not universally welcome, element of the European military landscape: equally, the matrimonial aspirations of the Romanov dynasty promised to surpass the legendary achievements of Yaroslav the Wise in the $11^{\text {th }}$ century.

Peter's second voyage also made many other acquisitions in the fields of science, arts, and crafts that have since sunk deep roots into Russian soil. Many iconic objects of Russian cultural heritage were the results of this voyage, such as the world-famous Amber Room and the collection of 'naturalia' and 'monstruosos' of the Dutch anatomist Frederik Ruysch, which formed the basis of the first museum in Russia, the Kunstkamera of St Petersburg. The development of landscape and garden design in Russia, most remarkably at Peterhof, with its fountains and abundant palaces and manors, was triggered by the royal visit to Versailles, Trianon, and Marly. The Russian Academy of Sciences and its expeditions, the appearance of the first Russian tapestries and porcelain, new styles in portrait painting and sculpture - all these received a powerful impetus from the voyage of 1716-1717. Many European scientists, engineers, architects, and artists, personally invited by Peter the Great during his second trip to Europe, began to work in Russia.

Tsar Peter's prolonged stay abroad attracted the attention of European sovereigns and their courts and piqued the curiosity of many strata of the population, thus giving rise to a large number of disparate texts: diplomatic correspondence, reports, regulatory and financial records, newspaper articles, pamphlets, essays, and literature. These texts comprise a vast range of historical sources, providing the opportunity for a comprehensive international research programme dedicated to studying this event in terms of the widest possible historical and cultural contexts. The aforementioned Paris conference in June 2017 and the thematic collection of articles published in this and subsequent editions of $Q R$ can be regarded as the launch of this programme.

By terming the visit of Peter the Great to Paris in the spring and summer of 1717 a 'logical serendipity', we mean that the Russian tsar had long been interested in establishing strong relations with France and had previously made several attempts to this effect. For various reasons, however, rapprochement did not occur at the end of the seventeenth or in the first decade of the eighteenth centuries. Yet, a few years prior to Peter's historic visit to Paris, France has sent its representative to St Petersburg, one Henri Lavie, a merchant with a modest rank in France's maritime consulate. Anne Mezin (Archives Nationales, Paris) examines some of Lavie's activities and his private meeting with the tsar in 1715 , which formed the background to Peter's visit to the French capital in 1717. As a result of this meeting, Lavie was appointed as the first French ambassador to Russia.

The theme continues with the article by Sergey Mezin (Saratov University), a major specialist in the history of Russo-French relations in the first quarter of the $18^{\text {th }}$ century. "The Paris of Peter the Great" explores the cultural dimension of Peter's visit to France in 1717, including the experi- 
ences and 'lessons' that the Russian tsar derived from the trip. The author reconstructs the routes that Peter the Great took in Paris and studies the influence of the French capital's architecture and monumental art on the 'cultural policies' of the monarch.

Alexey Morokhin's (Nizhny Novgorod University) article focuses on the movements of Tsarina Catherine Alekseevna's convoy at the end of 1716. The tsar's spouse accompanied her husband, at times traveling with him and at others voyaging separately, in one case as far as the Netherlands. On the road, she had to endure very harsh circumstances, foremost among them a complicated birth which ended with the tragic death of the newborn and almost cost the tsarina her own life. Describing the circumstances of her trip, the author includes much new material: he looks at Catherine's mishaps on the road in terms of the overall political context, concluding that the particularities of her trip contributed to the deterioration of Russia's relations with its allies.

The movements of the tsar aroused keen interest among the monarchs of Europe. The tsar's visit to the French capital was of particular interest to the Austrian Empire, a rival of France in the recent War of the Spanish Succession. Steven Müller's (University of Jena, Germany) article examines the process of collecting and evaluating information on Peter I by the Austrian diplomat Joseph von Königsegg, the Imperial Envoy in Paris at the time. The article leads to the conclusion that Königsegg's ability to gather information was limited due to strained relations between the Viennese court and Versailles.

The desire to put new documents on Peter the Great's 1716-1717 trip into the public domain has prompted the editors to strengthen the source component of this issue. Dmitry Redin (Ural Federal University, Ekaterinburg) and Dmitry Serov (Novosibirsk State University of Economics and Management) have co-edited the first publication of a compilation of letters sent by Vice-Chancellor Peter Shafirov to Prince Alexander Menshikov at the end of the 1716. Shafirov, one of the leaders of the Russian diplomatic office and the tsar's confidant, had been accompanying him on the tour and serving as a translator during Peter's most sensitive meetings with European monarchs: he had an intimate knowledge of the finest minutiae of the tsar's diplomatic affairs and everyday chores. The letters reveal many unknown details about Peter's stay in Denmark, Prussia, Hanover, and the Netherlands.

Lorenz Erren (University of Mainz), publishing the documents of Baron Friedrich Ernst von Cnyphausen, the Prussian envoy in Copenhagen, analyses one of the key episodes of the Great Northern War: the preparation and failure of allied forces during the Schonen Expedition of 1716. Documents show that the reasons for the failure of the operation in Skane were the machinations of Anglo-Hanoverian diplomacy and an 'irrational Russophobe hysteria' that subsequently encompassed the Danish court. Prussia, apparently the only firm ally of Russia at the time, understood the true causes of the sentiment at the Danish court and was interested in the military success of St Petersburg. 
The Petrine theme in the second issue of Quaestio Rossica for 2017 is concluded with a piece by Armelle Le Goff (Archives Nationales, Paris) and Olga Okuneva (Institute of World History, Russian Academy of Sciences, Moscow). Here, the authors reconstruct the history of an anatomical model of the brain and skull by Joseph-Guichard Duverney, anatomy professor and member of the Paris Academy of Sciences, and its acquisition by Tsar Peter I: it became one of the first exhibits of the Kunstkamera. This analysis allows the researchers to trace the evolution of the tsar's views on establishing natural science collections in Russia.

The European lifestyle and achievements that Peter's trip helped bring to Russia continued to develop in the court's performative practices in the $18^{\text {th }}$ century. Based on the descriptions of British subjects, Matthew Binney (Eastern Washington University) employs a semiotic analysis of imperial celebrations and their impact on observers: the patriotic pathos of the performances contributed to the sense of the greatness of the state.

Of utmost importance for European social thought, 'social contract theory' had its supporters in Russia not only among politicians, but also in some poetic works. From the late $17^{\text {th }}$ to the late $18^{\text {th }}$ centuries, the Russian ode successfully recast this European idea into artistic reality, as Tatiana Abramzon and Alexey Petrov (University of Magnitogorsk) demonstrate. In their opinion, the circle of poets engaged with such ideas was quite wide: poetic descriptions reworked the theory in relation to the image of an enlightened monarch.

The inner world of the 'ideal monarch', which Catherine II of Russia imagined she represented, was the focus of her memoirs. Here, we present Russian and Bulgarian authors researching her autobiographical work from different perspectives. Tatiana Akimova (University of Saransk) draws attention to the poetic device of 'gallant conversation', which was popular in European literature of the time. This gave the imperial author the chance to simultaneously create theatrical and novelistic chronotopes. Akimova concludes that this allowed Catherine II to show the merging of the public and private spheres in her acts and to declare that her life goal was to attain the love of her subjects.

The article by Angelina Vacheva (Sofia University, Bulgaria) considers Catherine the Great's self-censorship, which she discovers by comparing various editions of her memoirs. The author is thus able to see Catherine's changing attitudes towards the previous empress and other characters. With time, the idea of the proper handing over of imperial power grows stronger, leading the author of the memoirs to soften her earlier negative attitude towards the role and character of Empress Elizabeth.

The name of Pancraty Sumarokov is less well known than that of his uncle, the poet Alexander Sumarokov. Pancraty's life, full of hardships during his long exile in Tobolsk, was nevertheless filled with creative writing. Translated from French, his 'English story' Uchilishche liubvi ['The School of Love'] was one of the manifestations of his creativity. Using the pioneering methods of contextual and structural-typological 
analysis, Natalya Dvortsova (Tyumen University) takes into account the characteristics and functions of translated literature and finds the text to be original and professionally written. At the heart of Sumarokov's work, the researcher discovers the idea of interaction between Russian and European traditions, the meeting of 'ours' and 'theirs': this was necessary for the development of the new Russian literature.

The Disputatio section of this issue provides two articles focused on experiencing the horrors of war. In the article by Hartmut Rüss (University of Münster, Germany), '8/9 May 1945 and the Long Shadows of War', the reader will find a unique combination of the biographical experiences of the postwar generation and the reflections of a professional historian. The author's humanistic position, depth, and pursuit of objective understanding are deeply appealing. The second article belongs to the famed linguist Valery Mokiyenko (St Petersburg University): in it, he presents a book of poems entitled Chas muzhestva ['The Hour of Courage'], which was created in the war-torn zone of Donbass. All the poets in the collection have been touched by the bitter winds of the tragic war in this region. Their art frequently contains strong Biblical allusions: this poetic device contributes to the profound meaning of the works, allowing the vulnerable and fragile position of a particular people to assume universal significance.

Finally, Alexander Filyushkin (St Petersburg University) looks at the current situation in Belarus as the country seeks to define its own identity. The Middle Ages has been elevated into a key period in the formation of the Belarusian state and culture: this is visually expressed in the symbolism of coats-of-arms and urban sculpture and has been further popularised by history textbooks and research. The author explores whether this approach is problematic.

Dmitry Redin, Larisa Soboleva

Ural Federal University, Ekaterinburg

Translation by Anna Dergacheva

Триста лет тому назад завершилось более чем полуторагодичное путешествие царя Петра I по ряду стран Восточной, Центральной и Западной Европы (1716-1717), его кульминацией стало посещение российским монархом Парижа и установление постоянных дипломатических отношений между Россией и Францией. Это событие послужило поводом для проведения ряда научных и культурных мероприятий в России и Франции, среди которых международная конференция «Le deuxième grand voyage de Pierre le Grand en Europe (1716-1717)», прошедшая в Париже в июне 2017 г. Первый блок статей, написанных на основе докладов, прозвучавших на конференции, составил тематическое ядро публикуемого номера ${ }^{1}$.

${ }^{1}$ Продолжение темы запланировано в четвертом выпуске $Q R$ за 2017 г.

(c) Dergacheva A., translation, 2017 
Этот юбилей был актуализирован визитом во Францию Президента Российской Федерации В. В. Путина и его встречей со вновь избранным Президентом Пятой республики Э. Макроном. Оба лидера не смогли обойти вниманием эту тему, коснувшись событий трехсотлетней давности на своей совместной пресс-конференции, а позже посетив выставку в Версале «Царь Петр во Франции, 1717 год».

Второе европейское турне Петра само по себе заслуживает самого пристального внимания и достойно гораздо более интенсивных исследовательских усилий, чем это можно было наблюдать по сей день. И главная проблема заключается в том, что, в отличие от первого путешествия, совершенного молодым царем в составе Великого посольства в 1697-1698 гг., современная наука не располагает целостным взглядом на путешествие 1716-1717 гг. Недостаточно изученными остаются даже вопросы хронологии и периодизации этого вояжа, установление мотиваций царских передвижений по Европе. В отличие от Великого посольства, имевшего определенную цель, диктовавшую и его маршрут, второе путешествие изначально не планировалось столь длительным и масштабным: потребность его продолжения определялись российским монархом ситуативно, под влиянием динамично менявшейся дипломатической конъюнктуры и событий Великой Северной войны. Это касалось и Парижа, посещение которого стало «закономерной случайностью».

Результаты этого турне позволяют говорить, что оно стало событием не только для истории России, но имело большое влияние на общеевропейский контекст, как актуальный, так и перспективный. В ходе второго путешествия Россия впервые показала себя в роли одного из ключевых игроков очередного передела Европы (а для того времени, по сути, мира). Европы, ставшей другой после войны за испанское наследство; Европы, становящейся другой ввиду явного заката гегемона Севера - Швеции; Европы, формировавшей стратегию баланса сил великих держав, среди которых место России стало очевидным даже для самых закоренелых скептиков. В ходе путешествия 1716-1717 гг. русская дипломатия совершенствовала свое мастерство и набирала вес; русские армия и флот становились привычной, хотя далеко не для всех приятной данностью европейского военного ландшафта, а матримониальные устремления русского царствующего дома обещали вскоре превзойти по своей широте успехи легендарных времен Ярослава.

Но второе путешествие имело и другие приобретения в области науки, искусств и ремесел, пустивших глубокие корни на русской почве. Многие знаковые сейчас для национального культурного достояния объекты стали результатом этого вояжа. Среди них, например, Янтарная комната и коллекция «натуралий» и «монструозов» Фредерика Рюйша, заложившие основу первого русского музея - Кунсткамеры. Садово-парковое искусство, Петергоф с его фонтанами и последующее дворцовое и усадебное строительство обязаны царскому посещению Версаля, Трианона и Марли. Академия наук и ее 
последующие экспедиции, русские гобелены и фарфор, портретная живопись и скульптура - все получило мощный стимул к развитию. Многие европейские ученые, инженеры, архитекторы, художники, приглашенные Петром во время его второго путешествия в Европу, стали служить и творить в России.

Длительное пребывание царя Петра за границей приковывало внимание дворов европейских суверенов и вызывало любопытство обывателей, а это породило огромное количество разнородных текстов: дипломатической переписки, отчетов, донесений, нормативной и финансовой документации, газетных публикаций, памфлетов, сочинений художественных жанров - всего того, что на сегодняшний день составляет необозримый круг исторических источников, дающих потенциальную основу для реализации комплексной международной исследовательской программы, посвященной изучению этого феномена в широком историко-культурном контексте.

Упомянутую выше июньскую конференцию в Париже и тематическую подборку статей, публикуемых в этом и последующем выпусках $Q R$, можно рассматривать в качестве заявки на начало реализации этой программы. Назвав ранее визит Петра I в Париж весной-летом 1717 г. «закономерной случайностью», мы имели в виду то, что русский царь давно интересовался установлением прочных отношений с Францией и предпринимал к тому несколько попыток и ранее. По разным причинам в конце XVII - первом десятилетии XVIII столетия этого сближения не произошло. Тем не менее, за несколько лет до исторического визита в Париж Петра Франция обзавелась своим представителем в Петербурге - Анри Лави, имевшим скромный ранг и полномочия морского консула королевства. Анна Мезин (Национальный архив, Париж) предлагает вспомнить эпизоды деятельности Лави и его личную встречу с царем в 1715 г. в качестве предыстории посещения Петром французской столицы в 1717 г. Ее результатом стало получение Анри Лави полномочий первого посла Франции в России.

Тема продолжается статьей крупного специалиста по истории русско-французских отношений первой четверти XVIII в. Сергея Мезина (Саратовский университет) «Париж Петра Великого». В ней рассматривается культурный аспект визита Петра I во Францию 1717 г. парижские впечатления и «уроки» русского царя, реконструируются его парижские маршруты и исследуется влияние архитектуры и монументального искусства французской столицы на «культурную политику» монарха.

Статья Алексея Морохина (Нижегородский университет) фокусирует внимание на передвижениях поезда царицы Екатерины Алексеевны в конце 1716 г. Супруга государя сопровождала мужа, следуя то вместе с ним, то отдельно вплоть до Нидерландов. Ей пришлось выдержать очень суровые испытания: беременность и тяжелые роды, закончившиеся трагической смертью младенца и едва не стоившие жизни самой царице. Описывая, в том числе и на основе впервые при- 
влекаемого материала, обстоятельства дорожных мытарств Екатерины, автор включает ее дорожные злоключения в общеполитический контекст и делает вывод, что обстановка путешествия имела важные негативные последствия и способствовала ухудшению отношений России с ее союзниками.

Перемещения царя вызывали пристальный интерес монархов Европы. Посещение царем французской столицы представляло особый интерес для Священной Римской империи, недавней соперницы Франции в войне за испанское наследство. В статье немецкого историка Стефана Мюллера (Университет Йены, Германия) на основе неотредактированных дипломатических донесений Йозефа фон Кёнигсегга, имперского посланника в Париже, анализируется процесс сбора и оценки информации австрийским дипломатом о Петре. Автор подводит к мысли о том, что информационные возможности фон Кёнигсегга были ограничены ввиду напряженных отношений между Венским двором и Версалем.

Стремление сделать достоянием научной общественности новые документы, освещающие историю путешествия 1716-1717 гг., побудило редакцию усилить публикаторскую составляющую номера. Дмитрий Редин (Уральский федеральный университет, Екатеринбург) и Дмитрий Серов (Новосибирский государственный университет экономики и управления) публикуют подборку писем, отправленных подканцлером бароном Петром Шафировым светлейшему князю Александру Меншикову в конце 1716 - 1717 г. Барон как один из руководителей русского дипломатического ведомства и доверенных лиц царя сопровождал его в путешествии и, служа переводчиком при самых конфиденциальных встречах Петра с европейскими монархами, был посвящен в мельчайшие детали дипломатических и повседневных его забот. Письма открывают множество неизвестных деталей пребывания Петра I в Дании, в прусских и ганноверских владениях и в Нидерландах.

На основе публикуемых документов прусского посланника в Копенгагене барона Фридриха-Эрнста фон Кнюпгаузена Лорени, Эррен (Университет Майнца, Германия) анализирует один из ключевых эпизодов Великой Северной войны - подготовку и провал десанта сил союзников по антишведской коалиции в Сконе (1716). Документы показывают, что причиной неудачи операции в Сконе стали происки англо-ганноверской дипломатии и «иррациональная русофобская истерия», охватившая датский двор. Пруссия, ставшая на тот момент едва ли ни единственным дипломатическим союзником России, понимала истинные причины настроений при датском дворе и была заинтересована в военных успехах Петербурга.

«Петровскую» тему в этом номере замыкает публикация Армель Ле Гофø (Национальный архив, Париж) и Ольги Окуневой (Институт всеобщей истории РАН, Москва), в которой авторы реконструируют историю создания и приобретения Петром анатомической модели головного мозга и черепа, изготовленной профессором анатомии 
и членом парижской Академии наук Жозефом-Гишаром Дювернеем и ставшей одним из первых экспонатов Кунсткамеры. Документ позволяет проследить эволюцию взглядов царя на задачи формирования естественнонаучной коллекции в России.

Путешествия Петра, открывшие европейский стиль жизни и сделавшие европейские достижения в различных сферах притягательными для России, были продолжены в просветительских практиках XVIII в. Интересный феномен царских праздников в семантическом ключе и на основании описаний иностранцев раскрыт в статье Мэтью Бинне (Восточный университет Вашингтона). Патриотический пафос представлений должен был способствовать национальному чувству величия государства.

Важнейшая для европейской общественной мысли теория «общественного договора» не только имела своих сторонников в России среди политиков, но своеобразно преломлялась в поэтическом творчестве. Русскую оду периода конца XVII - конца XVIII в., успешно претворившую европейскую идею в художественную реальность, рассматривают Татьяна Абрамзон и Алексей Петров (Магнитогорский университет). По их заключению, круг поэтов, вовлеченных в сферу этих идей, был достаточно широк и транслировал теорию в связи с образом просвещенного монарха.

Внутренний мир идеального монарха, каким позиционировала себя Екатерина II, был в центре внимания ее записок-мемуаров. Авторы из России и Болгарии с разных позиций исследуют ее автобиографическое произведение. Татьяна Акимова (Мордовский университет) обращает внимание на поэтический прием «галантного диалога», распространенного в европейской литературе, дающий возможность венценосному автору воссоздать в тексте театральный и романный хронотопы одновременно. Это позволяет в единстве показать слияние общественного и личного в деяниях и декларировать в качестве жизненной цели любовь подданных к императрице.

В статье Ангелины Вачевой (Софийский университет) предметом рассмотрения стала автоцензура Екатерины II, выявляемая в процессе сопоставления различных редакций ее мемуаров. Текстологические наблюдения позволяют увидеть изменение отношения к образу предшествующей императрицы и других персонажей. Усиление идеи о преемственности власти вынуждает автора смягчить в мемуарах негативные оценки личности Елизаветы Петровны.

Имя Панкратия Сумарокова менее известно, чем имя его дяди, поэта Александра Сумарокова. Трудная жизнь Панкратия, долгое время пробывшего в тобольской ссылке, была наполнена творческим поиском. Одним из проявлений стала его «англинская повесть» «Училище любви», переведенная с французского, как уведомлял о том титульный лист издания 1789 г. Автор статьи Наталья Дворияова (Тюменский университет), впервые исследуя текст в рамках контекстного и структурно-типологического анализа на фоне особенностей 
и функций переводной литературы, приходит к заключению о его оригинальности и профессиональном владении автора навыками изложения. В основе творчества П. Сумарокова - идея взаимодействия русской и европейской традиций, встречи «своего» и «чужого», столь необходимая для становления новой русской литературы.

В рубрике Disputatio редколлегия соединила две статьи, посвященные переживаниям ужасов войны. В статье Хартмута Рюсса (Вестфальский университет имени Вильгельма, Германия) «8-9 мая 1945 года и длинные тени войны» перед нами предстает уникальное соединение личного биографического опыта человека послевоенного поколения с размышлениями профессионального историка ${ }^{2}$ Привлекательны его гуманистическая позиция, человеческая глубина и стремление к объективному пониманию событий. Вторая статья принадлежит перу известного лингвиста Валерия Мокиенко (СанктПетербургский университет), презентующего книгу стихов «Час мужества», созданную в горячей точке войны - Донбассе. Всех поэтов коснулся горький ветер военной трагедии; современные события, к которым автор чувствует сопричастность, перекликаются с библейскими сюжетами и образами. Этот поэтический прием, по мысли исследователя, придает произведениям глубокий смысл: судьбы конкретных людей получают общечеловеческие обобщения через библейский контекст.

Современная ситуация в Белоруссии, стремящейся определить собственную идентичность, прослежена в статье Александра Фuлюшкина (Санкт-Петербургский университет). Активное обращение к Средневековью, визуально выраженное в символике гербов, городской скульптуре, растиражированное в учебниках истории и научных трудах, возвеличивает значение этого времени для территории Белоруссии как периода формирования государственной и культурной основы. Насколько это спорно и проблематично, показывает автор статьи.

Дмитрий Редин, Лариса Соболева Уральский федеральный университет, Екатеринбург

${ }^{2}$ См. автобиографические размышления автора об интересе к русской теме: Rüß H. Family History and Interest in Russia // Quaestio Rossica. 2013. № 1. S. 13-26. 